\title{
Fire resistance and mechanical properties of powder-epoxy composites reinforced with recycled glass fiber laminate
}

\author{
Rafał Oliwa ${ }^{1)}$ *), Katarzyna Bulanda $^{1)}$, Mariusz Oleksy ${ }^{1)}$, Paulina Ostyńska ${ }^{2)}$, Grzegorz Budzik ${ }^{3)}$, \\ Magdalena Płocińska4), Sławomir Krauze ${ }^{5)}$
}

DOI: dx.doi.org/10.14314/polimery.2020.4.4

\begin{abstract}
In this article the effect of type and content of fractions of recycled glass fiber reinforced plastics (GFRP) on the mechanical properties and flame resistance of epoxy composites (EP) were investigated. For this purpose, post-production waste of glass fabric reinforced laminate with epoxy matrix containing $15 \mathrm{wt} \%$ of aluminum diethylphosphinate (AlDPi), $10 \mathrm{wt} \%$ of melamine polyphosphate (MPP) and $15 \mathrm{wt} \%$ of zinc borate (ZB) was ground and sieved to obtain four fractions of grain size: $>1 \mathrm{~mm}$ (A), 1-0.5 mm (B), 0.25-0.5 mm (C) and $<0.25 \mathrm{~mm}$ (D). The two smallest fractions (C, D) were used to prepare epoxy composites containing 10, 15 and $20 \mathrm{wt} \%$ of waste. The mechanical properties and fire resistance of obtained composites aimed as structural elements of seat equipment in public transport were determined. Scanning electron microscopy (SEM) was also performed to investigate the morphology of brittle fractures of epoxy composites. It was found that the amount and type of recyclated GFRP fraction affects the functional properties of powder-epoxy resin composites. The best results were obtained for the composite containing $15 \mathrm{wt} \%$ of the smallest fraction (D), as all mechanical properties were significantly improved [hardness $147.6 \mathrm{~N} / \mathrm{mm}^{2}(+42.5 \%)$, impact strength $9.64 \mathrm{~kJ} / \mathrm{m}^{2}(+11 \%)$, Young's modulus $2.98 \mathrm{GPa}(+41.5 \%)$, tensile strength $51.5 \mathrm{MPa}(+37 \%)$ and flexural strength $98.7 \mathrm{MPa}(+10.9 \%)]$. On the other hand, significant decrease in mechanical properties was observed for the composite containing $20 \mathrm{wt} \%$ of the fractions with grain size $0.5-0.25 \mathrm{~mm}$ (C). The analysis of the brittle fractions morphology of composites, indicates the weak dispersion and agglomerates formation in the case of composites with coarse-grained fractions. This also contributed to the flammability results. The highest flame resistance was found in the composite with $20 \mathrm{wt} \%$ of the fine-grained fraction: limiting oxygen index $L O I=26.1 \%$ instead of $20.6 \%$ - EP, peak of heat release rate $p H R R=540.3 \mathrm{~kW} / \mathrm{m}^{2}$ instead of $940.1 \mathrm{~kW} / \mathrm{m}^{2}-\mathrm{EP}$.
\end{abstract}

Keywords: powder-epoxy resin, composites, waste, recycling, mechanical properties, fire resistance.

\section{Odporność na płomień oraz właściwości mechaniczne kompozytów proszkowej żywicy epoksydowej wzmocnionej recyklatem laminatu z włóknem szklanym}

Streszczenie: Zbadano wpływ rodzaju oraz zawartości frakcji recyklatu laminatu z włóknem szklanym (GFRP) na właściwości mechaniczne oraz odporność na płomień kompozytów żywicy epoksydowej (EP). W tym celu zmielono odpady poprodukcyjne formatki fotela wykonanej z laminatu wzmocnionego tkaniną szklaną na osnowie żywicy epoksydowej, zawierającej 15\% mas. dietylofosfinianu glinu (AlDPi), 10\% mas. polifosforanu melaminy (MPP) oraz 15\% mas. boranu cynku (ZB). Otrzymano cztery frakcje o wymiarach ziaren: $>1 \mathrm{~mm}(\mathrm{~A}), 1-0,5 \mathrm{~mm}(\mathrm{~B}), 0,25-0,5 \mathrm{~mm}$ (C) oraz $<0,25 \mathrm{~mm}$ (D). Dwie najdrobniejsze frakcje (C, D) wykorzystano do sporządzenia kompozytów epoksydowych zawierających 10, 15 i 20\% mas. odpadów. Oceniono właściwości mechaniczne oraz odporność na płomień otrzymanych materiałów pod kątem zastosowania ich jako elementy konstrukcyjne fotela w publicznych środkach transportu. Najlepsze wyniki uzyskano w wypadku kompozytu zawierającego $15 \%$ mas. frakcji D, znacznie poprawiły się: twardość - 147,6 N/mm² (o 42,5\%), udarność - 9,64kJ/m² (o 11\%), moduł Younga

\footnotetext{
1) Rzeszow University of Technology, Faculty Chemistry, al. Powstańców Warszawy 6, 35-959 Rzeszów, Poland.

2) Rzeszow University of Technology, Faculty of Menagement, al. Powstańców Warszawy 8, 35-959 Rzeszów, Poland.

3) Rzeszow University of Technology, Faculty of Mechanical Engineering \& Aeronautics, al. Powstańców Warszawy 8, 35-959

Rzeszów, Poland.

4) Warsaw University of Technology, Faculty of Materials Science \& Engineering, Wołoska 141, 02-507 Warsaw, Poland.

5) SZTK TAPS Maciej Kowalski, Borowa 4, 94-247 Łódź, Poland.

*) Author for correspondence: oliwa@prz.edu.pl
} 
- 2,98 GPa (o 41,5\%), naprężenie rozciągające - 51,5 MPa (o 37\%) oraz naprężenie zginające - 98,7 MPa (o 10,9\%). Z kolei wyraźne pogorszenie właściwości mechanicznych zaobserwowano w wypadku kompozytu zawierającego $20 \%$ mas. frakcji o wymiarach ziaren 0,5-0,25 mm (C). Na podstawie wyników skaningowej mikroskopii elektronowej (SEM) morfologii kruchych przełomów otrzymanych kompozytów stwierdzono słabą dyspersję oraz powstawanie aglomeratów w kompozytach z frakcją gruboziarnistą, co miało również wpływ na palność badanych materiałów. Największą odpornością na płomień odznaczał się kompozyt zawierający 20\% mas. frakcji D: indeks tlenowy $L O I=26,1 \%$ (w odniesieniu do wartości LOI żywicy epoksydowej 20,6\%), maksymalna szybkość uwalniania ciepła $p H R R=540,3 \mathrm{~kW} / \mathrm{m}^{2}$ (w porównaniu z pHRR żywicy EP - 940,1 kW/m²).

Słowa kluczowe: proszkowa żywica epoksydowa, kompozyty, odpady, recykling, właściwości mechaniczne, odporność na płomień.

Fiber-reinforced polymer composites become the basic construction material used in many industries. Thanks to their unique functional properties, they are the main material for the production of primary and secondary structural components in public transport. For several years, an increase in the production of thermoset composites reinforced with glass fiber has been observed, which in 2018 reached the level of 971 thousand tons in Europe [1, 2]. The growing range of applications of polymer fiber composites is also increasing the amount of post-production and postuse waste, therefore it is important to develop the possibilities of utilization and reuse of polymer fiber composites. Unfortunately, composites reinforced with continuous fibers are difficult to recycle $[3,4]$. The difficulty of the recycling technology of fiber-reinforced polymer composites is that it is very difficult to obtain individual components of the composition. Usually, the fiber, filler materials and thermoset matrix that once crosslinked can't be reformed remain still bound [5]. However, the materials may provide similar benefits to conventional additives [6]. In the textile industry, fibrous waste accounts for about $15 \%$ of the fiber amount, so scientists are still looking for techniques to use recyclate from polymeric materials filled with fiber, especially glass fiber. Recycling of polymeric composites is a major challenge for modern engineers and is the subject of many research works aimed at developing methods of reuse of the resulting waste [7]. Among the various technologies of polymer composites recycling one can distinguish pyrolysis $[8,9]$, oxidation in a fluidized bed [10-12], chemical treatment [13-16] and mechanical grinding [17-19]. Despite intensive research on the optimization of individual composite recycling technologies, it has not yet been possible to transfer them economically and efficiently on an industrial scale. This fact makes material recycling a widely used method of laminate recycling in many companies. Mechanical recycling is the processing of composites by grinding, crushing, screening leading to the production of resin and fibrous powdered fractions. It concerns mainly composites reinforced with glass fabric, because CF (carbon fiber) materials are difficult to grind and often lead to equipment failure [7]. One of the undoubted advantages of the method of reuse of polymeric composite waste is the simple technology, which does not require the use of expensive and complicated apparatus.
Thanks to proper grinding, composite waste can be used as fillers in composites. During mechanical recycling, the aim is to obtain as much fibrous fraction as possible, as the recycled glass fiber gives structural integrity to the polymer matrix [20] and improves mechanical properties. Such fibrous fractions from duroplastic matrix composites are widely used to reinforce thermoplastics [21, 22] as well as thermosetting plastics, where recycled glass fibers are used as fillers to reduce the amount of pristine glass fibers [23] or as the main reinforcement in composites [24]. Beauson and others [25] used wind turbine blades to produce polyester composites containing 10, 20 and 30 wt \% of the powder-fiber fraction. After grinding and screening, they obtained fine-grained and coarse-grained fractions of 0.8 and $30 \mathrm{~mm}$ length of glass fibers and $74 \mathrm{wt} \%$ content, respectively. They observed that the stiffnesses of the composites are higher than the stiffness of the pure polyester plate. Higher modulus increase from 26 to $70.5 \%$ was obtained in case of composites with coarse-grained fraction. The tensile strength, on the other hand, has significantly deteriorated. Based on SEM analysis of large fiber/matrix debonding cracks at the fracture surfaces of the composites, they found that the low failure strength and strain of the composites is due to insufficient bonding between the recycled fiber and the new polyester matrix. Hanan et al. [26] have also showed that the addition of fine- and coarse fraction to unsaturated polyester resin (UPR) improves the modulus of composites. The composites with coarse fraction which contain relatively larger aspect ratio (longer fiber length) have better stiffness than these with fine rGF (recycled glass fiber). Nevertheless, composites containing recyclate had a lower tensile strength than UPR, except for the sample containing $30 \mathrm{wt} \%$ coarse-grained fraction. In turn, Kalebek has investigated the flammability behavior of epoxy composites reinforced with recycled glass/cotton fiber coated with a flame retardant. The obtained results showed that percentage of natural fibers has positive effect on improving flammability behavior of fabrics [27].

On the basis of the literature review the flammability and mechanical properties of powder-epoxy composites containing fibrous-powder recyclate have not been investigated. The polymeric construction materials must fulfill the applicable fire protection requirements, which are particularly important for composites used in the automo- 
tive industry. Therefore, the objective of the present study was to investigate the influence of type and content of the fraction of recycled GFRP on the flammability and mechanical properties of powder-epoxy composites, used as the main structural element of the seat in public transport.

\section{EXPERIMENTAL PART}

\section{Materials}

The shredded composite materials come from postproduction and defective elements of the seat manufactured by SZTK TAPS from Lodz (Poland). Before grinding, the composite waste consisted of: $55 \mathrm{wt} \%$ of glass woven roving fabric $\left(2 / 2,350 \mathrm{~g} / \mathrm{m}^{2}\right), 25.5 \mathrm{wt} \%$ of powderepoxy resin, $6.75 \mathrm{wt} \%$ of aluminum diethylphosphinate (AlDPi), $4.5 \mathrm{wt} \%$ of melamine polyphosphate (MPP) and $6.75 \mathrm{wt} \%$ of zinc borate (ZB) [28]. During the mechanical recycling process the $6-11 \mathrm{~mm}$ thick composite waste were cut into smaller fragments of approx. $4 \times 15 \mathrm{~cm}$ ones first, then the obtained fragments were ground using a knife mill with mesh size $2 \mathrm{~mm}$. The obtained recyclate containing fiber fragments, crushed resin and flame retardants was mechanical sieved to obtain four fibrouspowder fractions of the following average size: $>1 \mathrm{~mm}$ (48.7\%), 1-0.5 mm (20.0\%), 0.5-0.25 mm (17.5\%), <0.25 mm (13.5\%) marked as: A, B, C and D, respectively. Onecomponent powder-epoxy resin A.S.SET Powder 01 produced by New Era Materials Plant (Poland) was used to obtain composites containing GFRP recyclates. The powder resin was sieved with a mesh size of $0.25 \mathrm{~mm}$.

\section{Preparation of epoxy composites with recycled GFRP}

Epoxy resin compositions containing 10, 15 or $20 \mathrm{wt} \%$ of recyclate C or D marked as C10, C15, C20 and D10, D15, D20, respectively, were prepared. The compositions were blended in a high shear mixer (Dispermat CN40 produced by VMA-Getzmann, Gmbh) with a propeller stirrer in the vessel, for 15 minutes, at velocity of $2000 \mathrm{rpm}$. The epoxy composites were formed by compression molding technique, with the use of a hydraulic press (Carver, USA). For this purpose, the powder-epoxy compositions, were poured into the mold and subjected to a two-stage forming process, at the temperature of $120^{\circ} \mathrm{C}$ and the pressure of $2 \mathrm{MPa}$ applied for $2 \mathrm{~min}$, and subsequently $5 \mathrm{MPa}$ for $14 \mathrm{~min}$. The samples (dumbbell, bars and plates) were cut using a milling machine from the obtained plates with a surface area of $400 \mathrm{~cm}^{2}$ and approx. $4 \mathrm{~mm}$ thick. After two days mechanical properties and flame resistance of prepared specimens were tested according to relevant standards.

\section{Methods of testing}

In order to characterize the obtained powder-fiber fractions, investigation using optical microscope Vision
Engineering SX 45, up to 6x magnification and scanning electron microscopy (SEM, HITACHI SU800) were carried out. In addition, the glass fiber content in fractions was determined by combustion in a crucible according to ISO PN-EN ISO 1172:2002.

The limiting oxygen index (LOI) for the composites was determined according to the standard EN ISO 4589 at room temperature using an instrument of Fire Testing Technology Ltd. (United Kingdom).

The flammability tests by using UL-94 method were carried out in a chamber produced by FTT Ltd. (United Kingdom). The measurements were made according to standard PN-EN 60695-11-10 with vertical and horizontal sample beam position and methane fed burner of $25 \mathrm{~mm}$ height.

The heat release rate $\left(H R R\right.$ in $\left.\mathrm{kW} / \mathrm{m}^{2}\right)$ during sample combustion as well as other parameter characterizing flammability were evaluated for composite plates $100 \times 100 \times 2 \mathrm{~mm}$ in size using a cone microcalorimeter, a product of FTT Ltd. (United Kingdom), according to standard ISO 13927, by applying the heat flow $50 \mathrm{~kW} / \mathrm{m}^{2}$ and the distance from ignition source $25 \mathrm{~mm}$.

Tensile strength was studied according to ISO 527-1:1998 standard using Instron 5967 testing machine. Elongation speed was $2 \mathrm{~mm} / \mathrm{min}$ and measuring temperature was $23^{\circ} \mathrm{C}$.

The bending tests were performed according to PN-EN ISO178, using the same tensile machine equipped with a three point bending rig. The vertical displacement speed of the rig during the test was $2 \mathrm{~mm} / \mathrm{min}$.

Rockwell hardness was tested with ZWICK 3106 hardness tester, in accordance with EN 10109-1 standard. Indenter load equalled $358 \mathrm{~N}$.

Charpy impact resistance was determined according to PN-EN ISO 179-1 with Ceast 9050 Impact Pendulum (Italy), using hammer impact energy of $1 \mathrm{~J}$. Unnotched bars: $100 \mathrm{~mm}$ in length, $10 \mathrm{~mm}$ in width and $4 \mathrm{~mm}$ in height were applied.

The morphology of brittle fracture of composites was analyzed using a scanning electron microscope (SEM, HITACHI SU800). Fractured specimens were obtained after cooling in liquid nitrogen and impact-break. Fractured profiles were copper sputter-coated before observation. Observations were conducted at $5 \mathrm{kV}$ accelerating voltage of electrons with a 150× magnification.

\section{RESULTS AND DISCUSSION}

\section{Characteristic of recycled GFRP fractions}

Figure 1 shows the fraction of recyclated GFRP obtained after grinding and manual sieving. It was found, that the main component of the two fractions with the largest particle size are the long glass fiber bundles bonded with old resin and the resin particles (Figs. 1a, 1b). By visual inspection, the average fiber length for these fractions is in the range of $5-10 \mathrm{~mm}$. A fraction between 
a)

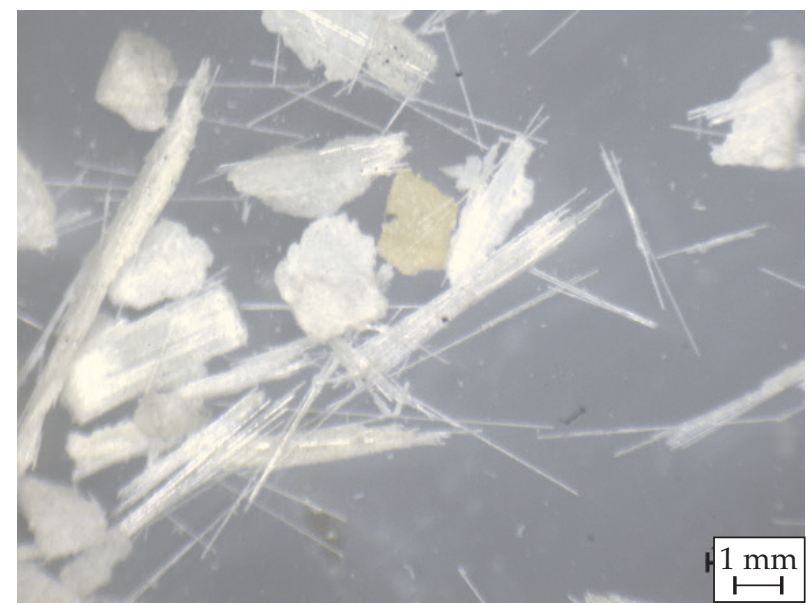

c)

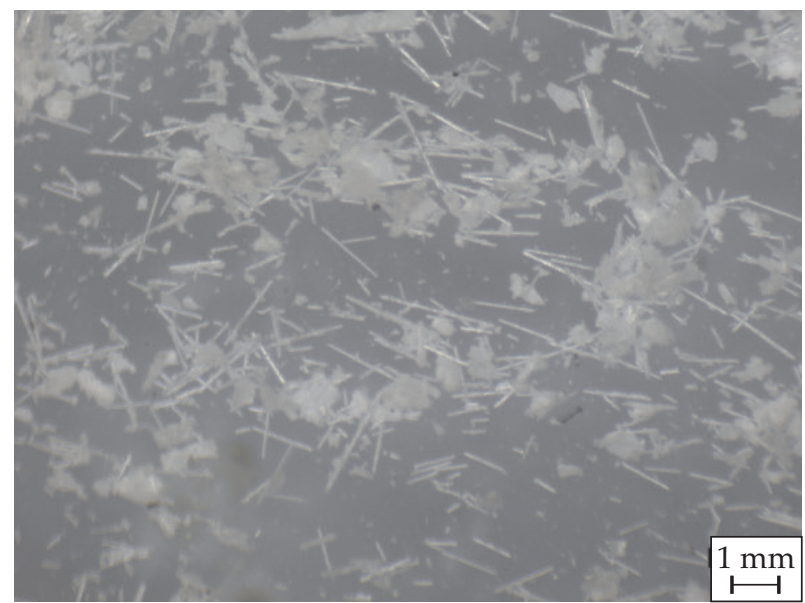

e)

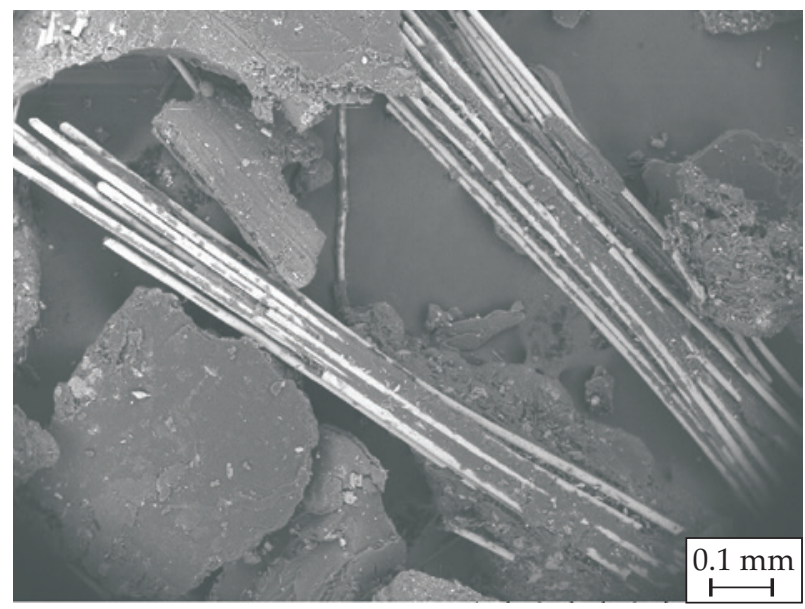

b)

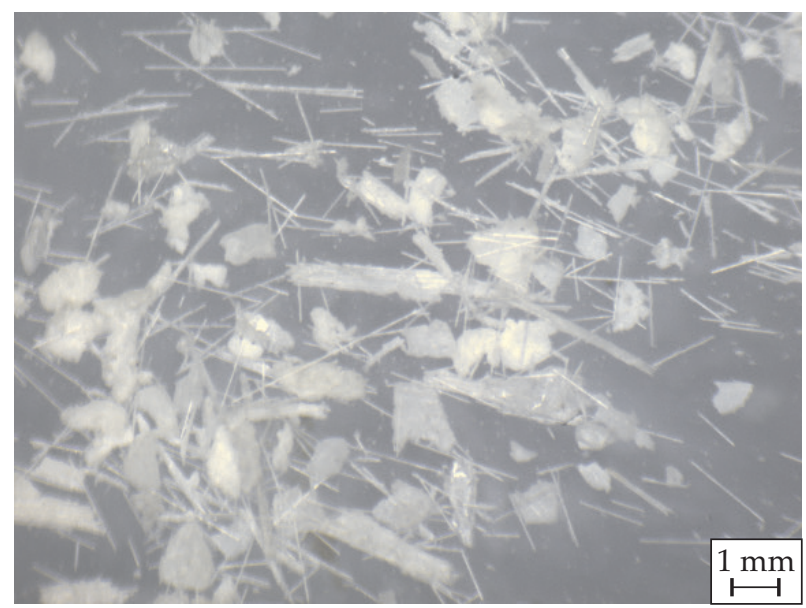

d)

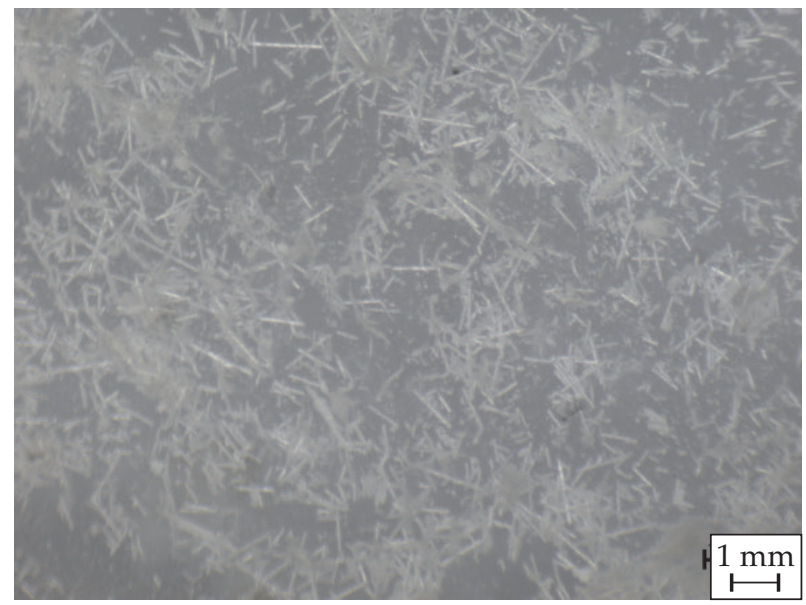

f)

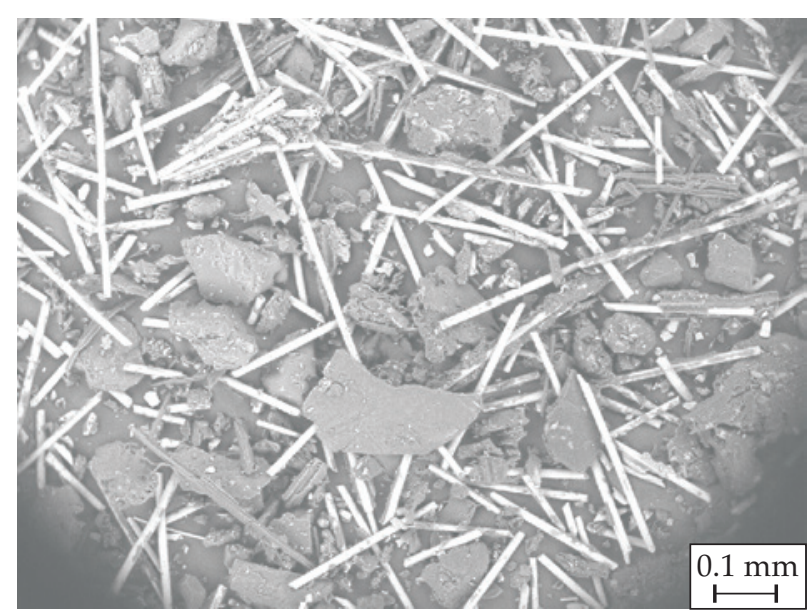

Fig. 1. Images of the recyclated GFRP fractions with average particle size: a) $>1 \mathrm{~mm}, \mathrm{~b}) 1.0-0.5 \mathrm{~mm}, \mathrm{c}) 0.25-0.5 \mathrm{~mm}$, d) $<0.25 \mathrm{~mm}$ taken with optical microscope at fivefold magnification, and SEM images of fine fractions with average particle size: e) $0.25-0.5$ mm, f) below $0.25 \mathrm{~mm}$ with a $200 \times$ magnification

0.25 and $0.5 \mathrm{~mm}$ in size also consists of epoxy matrix pieces and glass fiber bundles with attached old resin (Figs. 1c, 1e), but the fiber are shorter (about 1-2 mm). In turn, the fraction with particle size below $0.25 \mathrm{~mm}$ contains short glass fiber, which are separated from the small resin particles and constitute a separate component of the waste (Figs. 1d, 1f). The average fiber length in this frac- tion was $0.5-1.0 \mathrm{~mm}$. On the basis of the grain analysis, the fine-grained fractions with particle size $0.25-0.5 \mathrm{~mm}$ and below $0.25 \mathrm{~mm}$ marked as C and D, respectively, were used to obtain the composites. Furthermore, the weight analysis of these fractions showed that the fiber content in the $\mathrm{C}$ and $\mathrm{D}$ fractions was 34.5 and $37 \mathrm{wt} \%$, respectively. 
$\mathrm{T}$ a b 1 e 1. The results of flammability tests of unfilled EP and epoxy composites

\begin{tabular}{c|c|c|c|c|c|c|c|c}
\hline $\begin{array}{c}\text { Sample } \\
\text { symbol }\end{array}$ & $\begin{array}{c}H R R \\
\mathrm{~kW} / \mathrm{m}^{2}\end{array}$ & $\begin{array}{c}\mathrm{pHRR} \\
\mathrm{kW} / \mathrm{m}^{2}\end{array}$ & $\begin{array}{c}\text { TTI } \\
\mathrm{s}\end{array}$ & $\begin{array}{c}P M L \\
\%\end{array}$ & $\begin{array}{c}E H C \\
\mathrm{MJ} / \mathrm{kg}\end{array}$ & $\begin{array}{c}\mathrm{THR} \\
\mathrm{MJ} / \mathrm{m}^{2}\end{array}$ & $\begin{array}{c}\text { UL94 class } \\
\%\end{array}$ & $\begin{array}{c}\text { LOI } \\
\%\end{array}$ \\
\hline EP & $194.4 \pm 8.3$ & $940.1 \pm 28.5$ & $31 \pm 3$ & $96.3 \pm 0.3$ & $21.2 \pm 2.1$ & $57.4 \pm 2.1$ & $\mathrm{HB} 40$ & $20.6 \pm 0.2$ \\
EPC10 & $130.9 \pm 8.2$ & $755.6 \pm 23.6$ & $28 \pm 4$ & $92.9 \pm 0.8$ & $20.8 \pm 0.9$ & $44.5 \pm 0.9$ & $\mathrm{HB} 40 \mathrm{~b}$ & $22.3 \pm 0.2$ \\
EPC15 & $125.5 \pm 10.0$ & $652.1 \pm 30.9$ & $25 \pm 3$ & $91.5 \pm 0.4$ & $19.4 \pm 1.1$ & $43.9 \pm 2.6$ & $\mathrm{HB} 40 \mathrm{a}$ & $24.4 \pm 0.3$ \\
EPC20 & $121.6 \pm 16.2$ & $590.0 \pm 22.0$ & $30 \pm 5$ & $91.0 \pm 1.7$ & $17.9 \pm 0.7$ & $37.5 \pm 3.9$ & HB40a & $25.4 \pm 0.4$ \\
EPD10 & $126.4 \pm 4.2$ & $669.7 \pm 26.8$ & $24 \pm 3$ & $93.1 \pm 1.0$ & $19.8 \pm 2.8$ & $40.5 \pm 0.8$ & HB40b & $22.5 \pm 0.2$ \\
EPD15 & $126.8 \pm 3.7$ & $603.9 \pm 19.7$ & $25 \pm 3$ & $91.2 \pm 0.8$ & $18.6 \pm 1.3$ & $36.9 \pm 5.4$ & HB40a & $24.6 \pm 0.2$ \\
EPD20 & $114.4 \pm 9.9$ & $540.3 \pm 13.9$ & $29 \pm 3$ & $90.8 \pm 1.1$ & $18.2 \pm 1.7$ & $34.5 \pm 5.0$ & HB40a & $26.1 \pm 0.2$ \\
\hline
\end{tabular}

\pm standard deviation; HRR - heat release rate; $p H R R$ - peak heat release rate; TTI - time to ignition; $P M L-$ percent mass loss; EHC - effective heat of combustion; THR - total heat released.

\section{Flammability of epoxy composites}

The results i.e. arithmetic means from three tests of flammability for each epoxy composites with recycled fractions are collected in Table 1.

It was found, that the addition of recycled powderfiber fractions improves flame resistant of epoxy composites. Furthermore, the obtained results indicate that the LOI of composites increase with additives loading. As a result, composites containing $20 \mathrm{wt} \%$ of $\mathrm{C}$ and $\mathrm{D}$ fractions characterized by higher, about 23.3 and $26.7 \%$ of LOI, compared to reference sample, reaching the LOI value equal to 25.4 and $26.1 \%$, respectively. Despite this, these composites had the same HB40 flammability class as unfilled epoxy resin. The only difference was the degree of combustion of the individual samples. In the case of unmodified epoxy resin the samples were completely burned within the marked distance of $75 \mathrm{~mm}$, resulting in a burning rate of $37 \mathrm{~mm} / \mathrm{min}$. The composites containing $10 \mathrm{wt} \%$ of recyclates have stopped burning before the $100 \mathrm{~mm}$ mark, while, for materials with 15 and $20 \mathrm{wt} \%$ content of additives the flame didn't exceed the $25 \mathrm{~mm}$ mark. The obtained LOI results and UL94 flammability class indicate that the main fire retardancy mechanism is

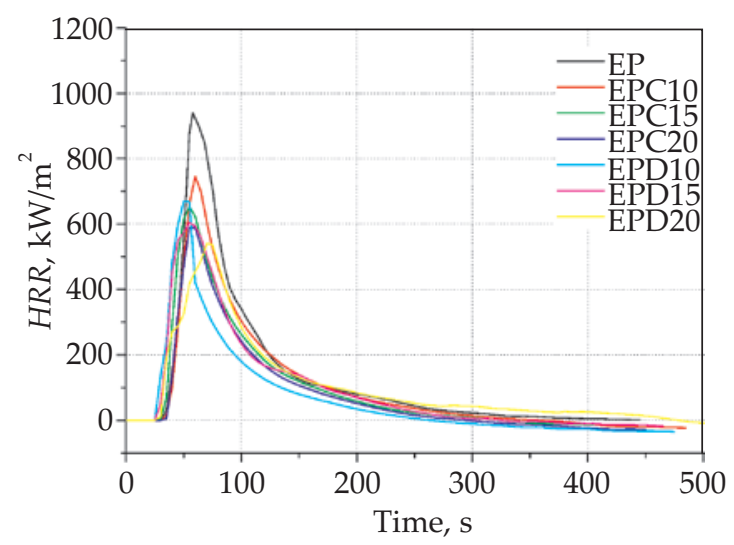

Fig. 2. Heat release rate $(H R R)$ curves as a function of time during flammability tests performed in the mass loss calorimeter of unfilled epoxy resin and epoxy composites dilution of combustible polymer, which results in lower intensity of pyrolysis [29]. As a result, in order to improve these flammability ratios, the recyclate content in composites should be significantly increased.

Flammability tests in a conical microcalorimeter were also carried out. Figure 2 presents representative curve for each samples, on the basis of which it was found that the composites containing recyclate burned more gently - the $p H R R$ is smaller and narrower.

This type of combustion may result from the presence of non-flammable additives which replace the flammable polymer. As a result, these materials emitted less heat. The data listed in the Table 1 is consistent with the recorded curves. The $p H R R, H R R, T H R$ and PML of composites decrease with an increase in recyclate loading. Again, the better results were obtained for composites containing a finer fraction. Additions of 10,15 and $20 \mathrm{wt} \%$ of $\mathrm{D}$ fraction caused a decrease in $p H R R$ by 28.7, 35.8 and $42.5 \%$, respectively, compared to unfilled resin. While, the THR of these materials decreased by 29.5, 35.7 and $37.9 \%$, respectively, in comparison to EP. On the other hand, effective heat of combustion (EHC) slightly decreased - with an increase in the content of filler, the $E H C$ reduced from 6.6 to $14.2 \%$, compared to $E H C$ value of reference sample.

A similarly small change has been observed for PML values. This indicates, that addition of powder-fibrous fractions to epoxy resin reduces the flammability by diluting the flammable polymer. According to literature [30, 31], the reduction of EHC is associated with the reduction of flammability in the gas phase, whereas the increase in the carbon residue indicates physical activity in the condensed phase [32,33]. As a result, the flame resistance increases with additives loading. Similar relationships were observed in the case of composites containing fractions with larger size of recyclate particles. However, these materials were characterized by higher values of the obtained parameters, which is consistent with the LOI results. This is probably due to the better dispersion of the smaller grain size recyclate (SEM analysis), which significantly improves the flame response of the composites. 
T a b l e 2. Mechanical properties of unfilled epoxy resin and epoxy composites

\begin{tabular}{l|c|c|c|c|c|c|c}
\hline \multirow{2}{*}{ Properties } & \multicolumn{7}{c}{ Sample symbol } \\
\cline { 2 - 7 } & EP & EPC10 & EPC15 & EPC20 & EPD10 & EPD15 & EPD20 \\
\hline $\begin{array}{l}\text { Ultimate tensile } \\
\text { strength, MPa }\end{array}$ & $37.6 \pm 3.5$ & $41.5 \pm 5.2$ & $38.4 \pm 6.4$ & $35.5 \pm 8.4$ & $43.9 \pm 3.6$ & $51.5 \pm 5.3$ & $39.5 \pm 5.4$ \\
$\begin{array}{l}\text { Young modulus, } \\
\text { GPa }\end{array}$ & $2.09 \pm 0.35$ & $2.91 \pm 0.15$ & $2.83 \pm 0.28$ & $2.32 \pm 0.37$ & $2.68 \pm 0.19$ & $2.98 \pm 0.33$ & $2.45 \pm 0.19$ \\
$\begin{array}{l}\text { Strain, \% } \\
\text { Flexural strength, }\end{array}$ & $2.50 \pm 0.24$ & $2.04 \pm 0.31$ & $2.43 \pm 0.33$ & $1.88 \pm 0.27$ & $2.39 \pm 0.21$ & $2.36 \pm 0.28$ & $2.33 \pm 0.27$ \\
MPa & $89.0 \pm 8.3$ & $67.4 \pm 6.5$ & $64.3 \pm 2.7$ & $65.1 \pm 4.5$ & $67.6 \pm 11.2$ & $98.7 \pm 0.5$ & $74.1 \pm 6.5$ \\
$\begin{array}{l}\text { Flexural modulus, } \\
\text { GPa }\end{array}$ & $2.75 \pm 0.24$ & $3.61 \pm 0.12$ & $3.17 \pm 0.10$ & $3.04 \pm 0.40$ & $2.61 \pm 0.40$ & $4.21 \pm 0.09$ & $3.38 \pm 0.07$ \\
Strain, \% & $4.70 \pm 0.37$ & $2.33 \pm 0.29$ & $2.30 \pm 0.14$ & $2.04 \pm 0.42$ & $2.92 \pm 0.23$ & $2.49 \pm 0.11$ & $2.39 \pm 0.22$ \\
Charpy impact, & $8.80 \pm 0.42$ & $9.30 \pm 0.25$ & $7.02 \pm 0.32$ & $6.26 \pm 0.23$ & $8.87 \pm 0.74$ & $9.64 \pm 0.18$ & $7.28 \pm 0.21$ \\
$\mathrm{~kJ} / \mathrm{m}^{2}$ & $103.6 \pm 8.4$ & $107.9 \pm 3.5$ & $106.7 \pm 2.8$ & $99.6 \pm 3.7$ & $125.8 \pm 6.8$ & $147.6 \pm 7.6$ & $108.7 \pm 5.5$ \\
Hardness, N/mm ${ }^{2}$ & & & & & & & \\
\hline
\end{tabular}

\section{Mechanical properties of epoxy composites}

\section{Tensile strength}

Based on the results presented in the Table 2, it was found that the addition of the powder-fibrous recyclate influenced the static tensile properties of epoxy composites. Furthermore, it has been observed that the amount of added recyclate as well as the size of fraction influence the change of these parameters.

As a result, the greatest improvement in tensile strength, by $37 \%$ in relation to unfilled resin, was obtained for the composite containing $15 \mathrm{wt} \%$ of finegrained recyclate D. This composite was also characterized by the highest Young's modulus value of $2.98 \mathrm{GPa}$, which is an increase of $0.9 \mathrm{GPa}$ in comparison to the reference sample. This indicates, that $15 \mathrm{wt} \%$ of the content is the optimal amount of these filler, as increasing the content of recyclate D to $20 \mathrm{wt} \%$ resulted in a slight increase of the Young's modulus and tensile stress, about 5 and $16 \%$, respectively, compared to reference sample. It may be caused by non-uniform mixing of powder-epoxy resin with additives. In turn, the composites containing fraction $C$ were characterized by a lower tensile stress and Young's modulus, in comparison with EPD composites, which is not in accordance with the literature data, because the coarse fraction contains longer fibers, which should promote greater strength [26, 27]. Among these materials, the best results (Young's modulus $2.91 \mathrm{GPa}$ instead 2.09 GPa, tensile strength $41.5 \mathrm{MPa}$ instead $37.6 \mathrm{MPa}$ ) were obtained for the EPC10. Interestingly, further increasing the content of this filler caused a decrease in the tested parameters. As a result, the EPC20 composite was characterized by ultimate tensile strength at the level of epoxy resin and the smallest Young's modulus among the composites containing recyclate. This is related to the larger size of the powder phase and the presence of fiber bundles, which causes irregular dispersion of the filler, especially in larger amounts - confirmed by SEM analy- sis. Non-uniform dispersion of the powder-fiber filler results in the formation of agglomerates, which affect the formation of internal stresses and promote crack propagation. As a result, despite higher fiber lengths present in the coarse phase compared to the fine-grained phase, composites with $\mathrm{C}$ fraction are characterized by tensile strength at the level of epoxy resin.

\section{Flexural strength}

In contrast to the results obtained during the static tensile test, the addition of recycled GFRP resulted in a deterioration of flexural strength of epoxy composites (see Table 2.). The exception is the composite containing $15 \mathrm{wt} \%$ of recyclate $\mathrm{D}$, which was characterized with higher flexural strength, about $11 \%$, than unmodified epoxy resin. Despite this, it was also found that the filling of epoxy resin with recyclates improved flexural modulus, which is associated with a significant increase in composites stiffness. Furthermore, the similar tendency regarding the Young' modulus was observed, as once again the greater improvements in the flexural modulus, by $1.52 \mathrm{GPa}$ and $2.12 \mathrm{GPa}$, were obtained for EPC10 and EPD15 composites, respectively. On the other hand, further increase in the content of recyclates resulted in a reduction of this effect. The obtained results confirm that using 10 and $15 \mathrm{wt} \%$ fraction $C$ and $\mathrm{D}$, respectively, gives the best improvement in bending and tensile strength of epoxy composites.

\section{Impact resistance}

The analysis of the impact strength results showed that the addition of recycled epoxy-glass filler affects the value of energy required to break the sample. The addition of recyclate of $0.25-0.5 \mathrm{~mm}$ size and $<0.25 \mathrm{~mm}$ size at $20 \mathrm{wt} \%$ caused a decrease in impact strength of the composites as compared to the unmodified polymer matrix. The lowest result was observed for the EPC20 composite, 
a)

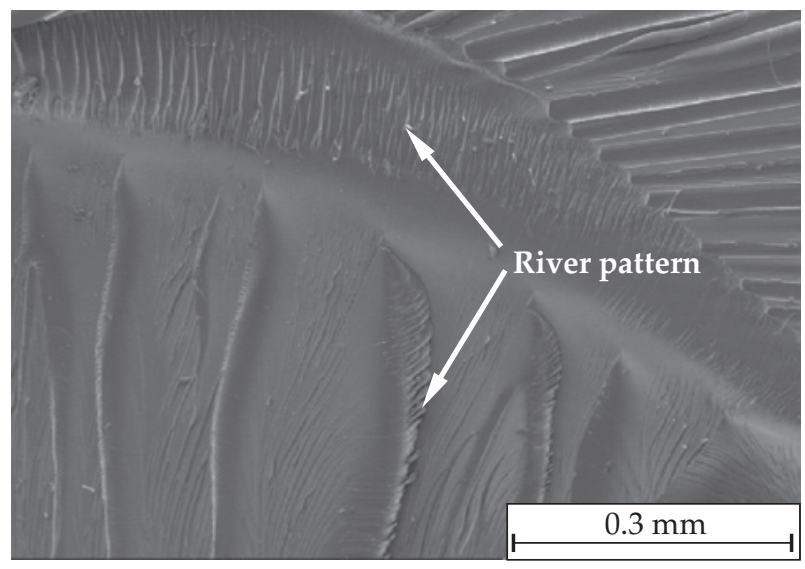

c)

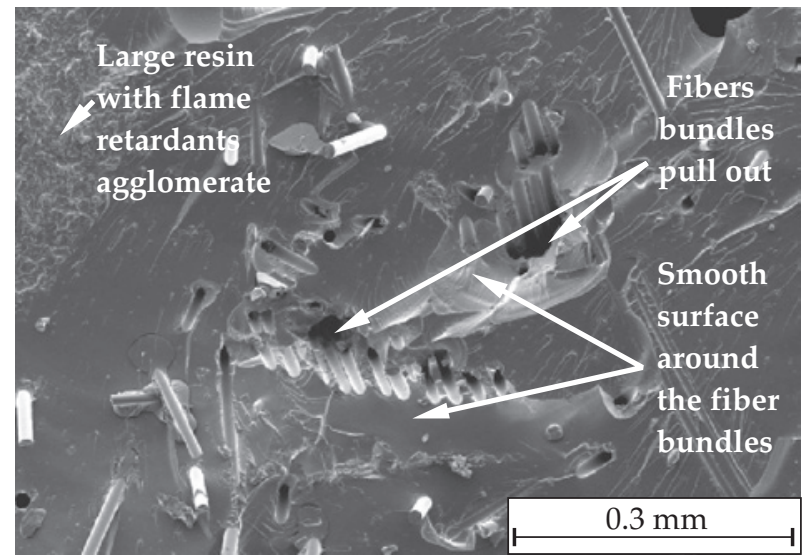

e)

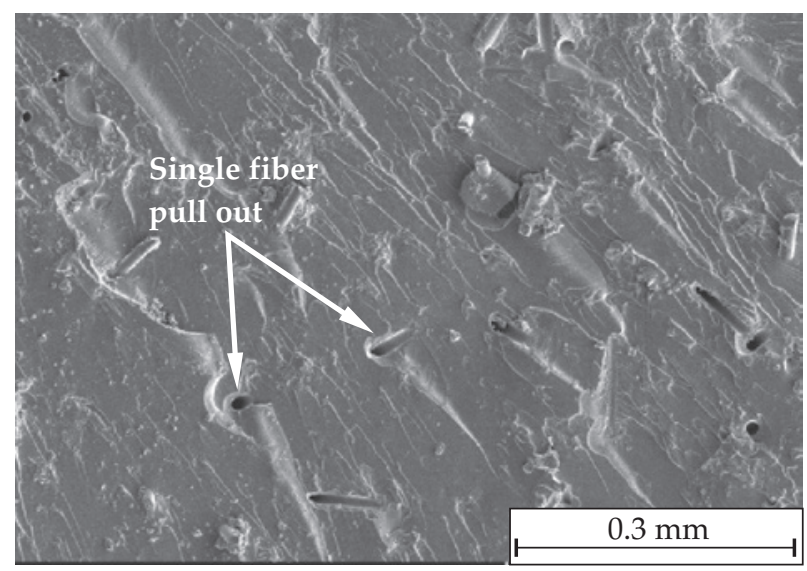

g)

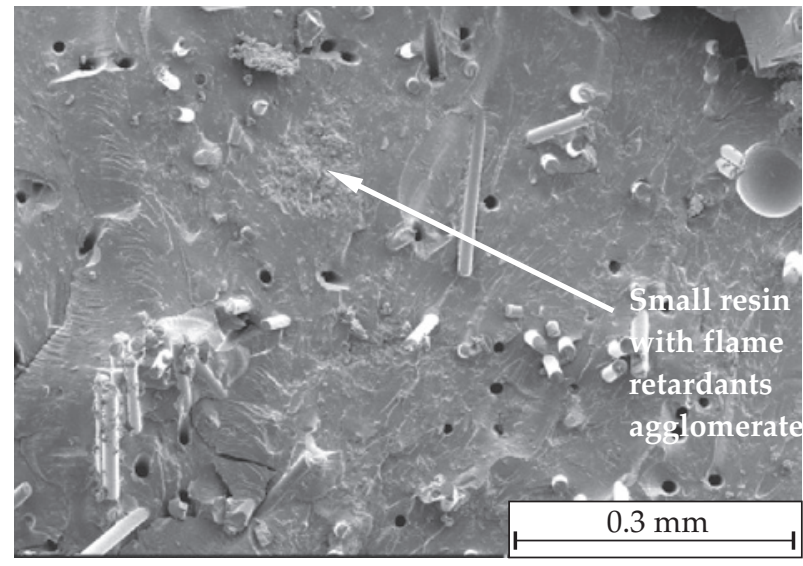

b)

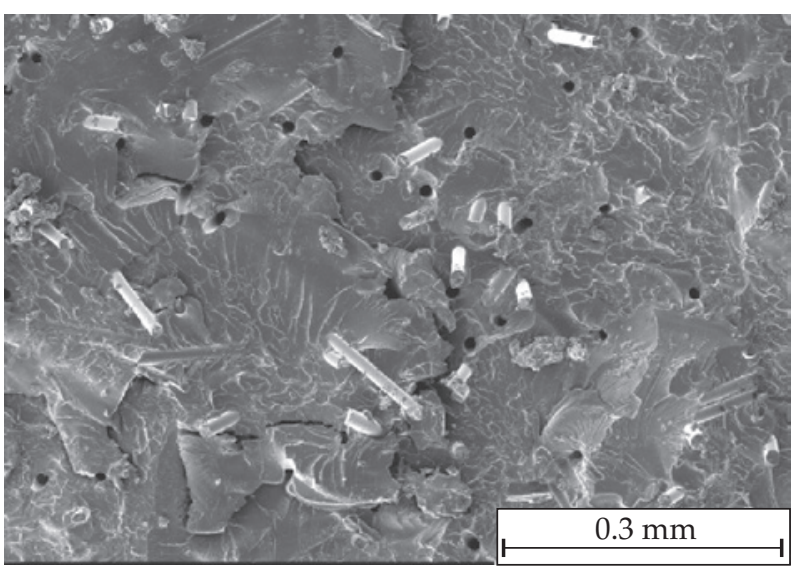

d)

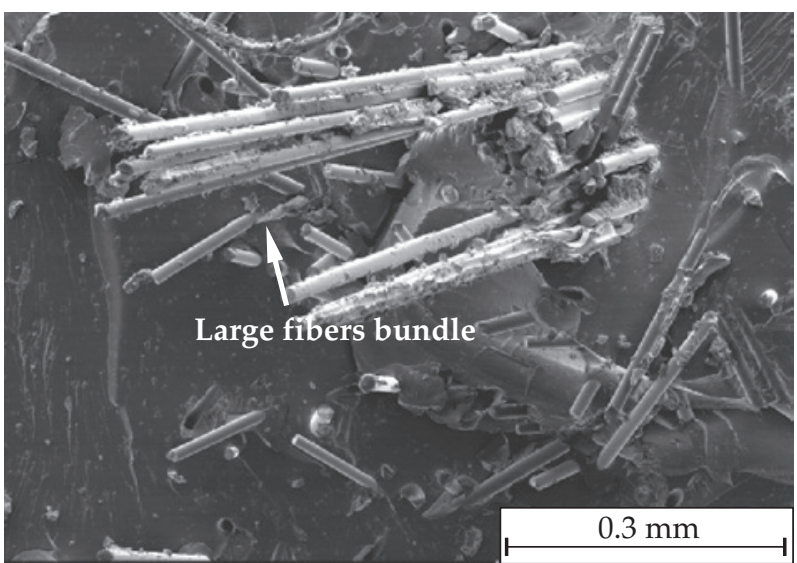

f)

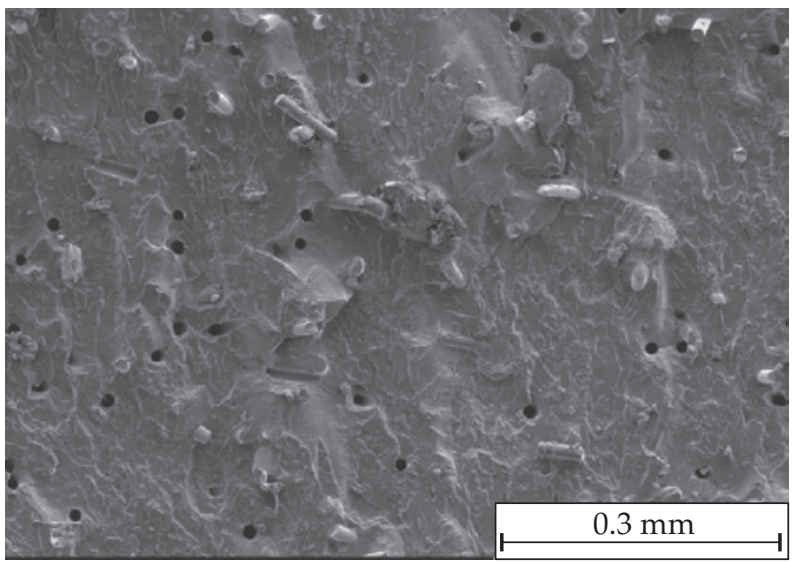

Fig. 3. SEM microphotographs of brittle fractures of: a) unmodified epoxy resin, and epoxy composites: b) EPC10, c) EPC15, d) EPC20, e) EPD10, f) EPD15, g) EPD20 
that has achieved impact strength equal $6.26 \mathrm{~kJ} / \mathrm{m}^{2}$. The presented occurrence is common for modified polymeric composites, especially with the addition of a filler in the irregular shape of particles, which often reaches insufficient dispersion in the polymer matrix [34]. Although the addition of $10 \mathrm{wt} \%$ of $\mathrm{C}$ fraction and $15 \mathrm{wt} \%$ of D fraction resulted in a significant increase in stiffness, EPC10 and EPD15 composites also exhibited improved impact strength, in contrast to the literature data - the impact strength decrease with recyclate loading [23]. The highest ability to carry violent shock type loads is demonstrated by EPD15, which reached $9.64 \mathrm{~kJ} / \mathrm{m}^{2}$ (instead of $8.80 \mathrm{~kJ} / \mathrm{m}^{2}$ ).

\section{Rockwell hardness}

The samples made of pristine epoxy resin showed a permanent deformation resistance of $103.6 \mathrm{~N} / \mathrm{mm}^{2}$. The Rockwell hardness for composites with coarse-grained fraction was at the same level as unfilled resin. In turn, the obtained results indicate that the composites containing recyclate with average particles size below $0.25 \mathrm{~mm}$ at 10 and 15 wt \%, impact strength increased of 22.2 and $44.0 \mathrm{~N} / \mathrm{mm}^{2}$, respectively, while slight improvement for EPD20 composite compared to reference sample was observed. On the basis of the obtained results, it was found that the introduction of larger amounts of recyclate into the polymer matrix may cause incorrect dispersion of the additive and the possibility of the formation of aggregates, which significantly affect the hardness of the composite.

\section{Morphology of epoxy composites}

Figure 3 shows representative microphotographs of brittle fracture surface of epoxy composites.

On the basis on the obtained microphotographs, it was found that applied parameters of compression molding press allowed for complete melting and bonding of resin grains. Furthermore, it can be seen, that the addition of powder-glass fractions significantly change the morphology of the composites. The surface after fracture of the neat epoxy resin is smooth, with visible characteristic for cured liquid resin design so-called river pattern (Fig. 3a) [35]. This indicates an easy crack propagation, which results in weak mechanical resistance of the epoxy resin. Compared to epoxy resin, the fracture surface of composites is more rough. In the case of composites containing fraction $\mathrm{D}$, the degree of surface texture increases with additives loading. The brittle fracture of EPD10 composite shows the striations with a few holes caused by fiber pulling out (Fig. 3e). Among these materials, the fracture surface observed from the EPD15 sample (Fig. 3f) indicates that the additives are better dispersed in the epoxy matrix as compared to this for EPD20 composite. In addition, uniformly dispersed single glass fibers were observed. As a result, composites containing 15 wt \% of D fraction were characterized by the best mechanical properties. In turn, in the microphotographs of brittle fracture surface of composites containing $20 \mathrm{wt} \%$ of fraction $\mathrm{D}$, the small agglomerations were observed (Fig. 3g). These agglomerations may have acted as flaws and crack initiation sites that resulted in poorer mechanical properties, in comparison with composites containing smaller amounts of $\mathrm{D}$ fraction. On the other hand, in the photos of brittle fractures of composites containing fractions of a grain size between 0.25 and $0.5 \mathrm{~mm}$, besides resin with flame retardants agglomerates, large particles of glass fiber bundles with attached old resin were observed (Figs. 3b, 3c, 3d). Furthermore, increasing the content of $\mathrm{C}$ fraction resulted in an increase of the agglomerates number and a decrease of the surface roughness. Around such agglomerates there is an easy cracking which is evidenced by the smooth surface of the crack - it is particularly visible in the marked place (Fig. 3c). This smooth surface of the brittle fracture in combination with the powder-fiber agglomerates results in a reduction in mechanical properties, compared to the unmodified matrix.

\section{CONCLUSIONS}

In this work the epoxy composites reinforced with recycled GFRP fractions were obtained. The shredded composites came from the post-production waste of public transport seat manufactured by TAPS from Lodz (Poland). On the basis of the obtained results, it was found that the amount and type of recyclated GFRP fraction affects the functional properties of epoxy resin composites. The best results were obtained for the composite containing $15 \mathrm{wt} \%$ of the smallest fraction. Hardness, impact strength, Young modulus, ultimate tensile strength, ultimate flexural strength and elastic modulus have been improved by 42.5, 11, 41.5, 37, 10.9 and 53\%, respectively, compared to unmodified resin. Moreover, although the $\mathrm{C}$ fraction contained fibers of higher length, these composites were characterized by lower strength and stiffness than the composites with D fraction, which is opposite to literature data $[26,27]$. It may be due to the presence of agglomerates formed during the mixing of powder materials. In addition, the coarse-grained phase contains particles of larger sizes and glass fiber bundles with attached old resin, which causes irregular dispersion of the filler, confirmed by the SEM analysis. These agglomerations may have acted as flaws and crack initiation sites, which resulted in poorer mechanical properties.

\section{ACKNOWLEDGMENTS}

Financial support from Structural Funds in the Operational Program - Innovative Economy, European Regional Development Fund - No. POIR.01.01.01-00-0158/16, "Industrial and development research into the design and production of prototypes for optional type series of innovative seats to be used as furnishing in public means of rail transport". 


\section{REFERENCES}

[1] Błędzki A.K., Gorący K., Urbaniak M., Scheibe M.: Polimery 2019, 64, 777. https://dx.doi.org/10.14314/polimery.2019.11.6

[2] JEC Composite Magazin 2019, March, nr 127.

[3] Kinvi-Dossou G., Boumbimba R.M., Bonfoh N. et al.: Composite Structures 2019, 217, 1. http://dx.doi.org/10.1016/j.compstruct.2019.02.090

[4] Ma Y., Nutt S.: Polymer Degradation and Stability 2018, 153, 307.

[5] Kocevar G., Krzan A.: Journal of Material Cycles and Waste Management 2018, 20, 1106. http://dx.doi.org/10.1007/s10163-017-0673-6

[6] Dehghan A., Peterson K., Shvarzman A.: Construction and Building Materials 2017, 146, 238. http://dx.doi.org/10.1016/j.conbuildmat.2017.04.011

[7] Rybicka J., Tiwari A., Leeke G.A.: Journal of Cleaner Production 2016, 112, 1001. http://dx.doi.org/10.1016/j.jclepro.2015.08.104

[8] Yang Y., Boom R., Irion B. et al.: Chemical Engineering and Processing: Process Intensification 2012, 51, 53. http://dx.doi.org/10.1016/j.cep.2011.09.007

[9] Nahil M.A., Williams P.T.: Journal of Analytical and Applied Pyrolysis 2011, 91, 67. http://dx.doi.org/10.1016/j.jaap.2011.01.005

[10] Pender K., Yang L.: Polymer Composites 2019, 40, 3510. http://dx.doi.org/10.1002/pc.25213

[11] Pickering S.J., Kelly R.M., Kennerley J.R. et al.: Composites Science and Technology 2000, 60, 509. http://dx.doi.org/10.1016/S0266-3538(99)00154-2

[12] Oyedun A.O., Lam K-L., Gebreegziabher T. et al.: Chemical Engineering Transactions 2012, 29, 655. http://dx.doi.org/10.3303/CET1229110

[13] Okajima I., Watanabe K., Haramiishi S. et al.: The Journal of Supercritical Fluids 2017, 119, 44. http://dx.doi.org/10.1016/j.supflu.2016.08.015

[14] Yan H., Lu C., Jing D. et al.: New Carbon Materials 2016, $31,46$. http://dx.doi.org/10.1016/S1872-5805(16)60004-5

[15] Oliveux G., Dandy L.O., Leeke G.A.: Polymer Degradation and Stability 2015, 118, 96.

http://dx.doi.org/10.1016/j.polymdegradstab.2015.04.016

[16] Liu T., Zhang M., Guo X. et al.: Polymer Degradation and Stability 2017, 139, 20.

http://dx.doi.org/10.1016/j.polymdegradstab.2017.03.017

[17] Palmer J., Ghita O.R., Savage L., Evans K.E.: Composites Part A: Applied Science and Manufacturing 2009, 40, 490. http://dx.doi.org/10.1016/j.compositesa.2009.02.002

[18] Oliveux G., Dandy L.O., Leeke G.A.: Progress in Materials Science 2015, 72, 61. http://dx.doi.org/10.1016/j.pmatsci.2015.01.004
[19] Liu Y., Farnsworth M., Tiwari A.: Journal of Cleaner Production 2017, 140, 1775. http://dx.doi.org/10.1016/j.jclepro.2016.08.038

[20] Bevis M.J., Bream C.E., Hornsby P.R. et al.: Materials, Functionality \& Design: Proceedings of the 5th European Conference on Advanced Materials and Processes and Applications/EUROMAT 97, Maastricht, NL, 21-23 April 1997, Vol. 2, pp. 219-221.

[21] Zhu P., Liu X., Wang Y. et al.: Journal of Environmental Chemical Engineering 2017, 5, 3439. http://dx.doi.org/10.1016/j.jece.2017.06.050

[22] Ogi K., Nishikawa T., Okano Y., Taketa I.: Advanced Composite Materials 2007, 16, 181. http://dx.doi.org/10.1163/156855107780918982

[23] Silva L.V., Angrizani C.C., Souza J.R.: Journal of Applied Polymer Science 2012, 124, 302. http://dx.doi.org/10.1002/app.34873

[24] Dangtungee R., Somchua S., Siengchin S.: Mechanics of Composite Materials 2012, 48, 325. http://dx.doi.org/10.1007/s11029-012-9279-1

[25] Beauson J., Madsen B., Toncelli C. et al.: Composites Part A: Applied Science and Manufacturing 2016, 90, 390.

http://dx.doi.org/10.1016/j.compositesa.2016.07.009

[26] Hanan U.A., Hassan S.A., Wahit M.U. et al.: International Journal of Advanced and Applied Sciences 2017, 4, 1 . http://dx.doi.org/10.21833/ijaas.2017.03.001

[27] Kalebek N.A.: Fibers and Polymers 2017, 18, 172. http://dx.doi.org/10.1007/s12221-017-6488-1

[28] Oliwa R., Oleksy M., Oliwa J. et al.: Polimery 2019, 44, 290. https://dx.doi.org/10.14314/polimery.2019.4.7

[29] Shukri T.M., Mosnacek J., Basfar A.A. et al.: Journal of Applied Polymer Science 2008, 109, 167. https://doi.org/10.1002/app.28080

[30] Wang J., Qian L., Xu B. et al.: Polymer Degradation and Stability 2015, 122, 8.

http://dx.doi.org/10.1016/j.polymdegradstab.2015.10.011

[31] Schartel B., Hull T.R.: Fire and Materials 2007, 31, 327. http://dx.doi.org/10.1002/fam.949

[32] Braun U., Schartel B., Fichera M.A. et al.: Polymer Degradation and Stability 2007, 92, 1528.

https://doi.org/10.1016/j.polymdegradstab.2007.05.007

[33] Braun U., Balabanovich A.I., Schartel B. et al.: Polymer 2006, 47, 8495.

http://dx.doi.org/10.1016/j.polymer.2006.10.022

[34] Salasińska K., Barczewski M., Górny R. et al.: Polymer Bulletin 2018, 75, 2511. http://dx.doi.org/10.1007/s00289-017-2163-3

[35] Zhou Y., Pervin F., Rangari V.K., Jeelani S.: Journal of Materials Processing Technology 2007, 191, 347. http://dx.doi.org/10.1016/j.jmatprotec.2007.03.059

Received 30 X 2019. 